\title{
Ingestion and assimilation of carbon from cellulolytic bacteria and heterotrophic flagellates by the mussels Geukensia demissa and Mytilus edulis (Bivalvia, Mollusca)
}

\author{
Daniel A. Kreeger*, Roger I. E. Newell \\ Horn Point Environmental Laboratory, Center for Environmental and Estuarine Studies, University of Maryland System, \\ PO Box 775, Cambridge, Maryland 21613, USA
}

\begin{abstract}
We ${ }^{14} \mathrm{C}$-labeled cellulolytic bacteria and 3 species of bacterivorous nanoflagellates and fed these cultured organisms to 2 species of intertidal mussels. Geukensia demissa and Mytilus edulis, using a pulse-chase experimental design under controlled laboratory conditions. Ingestion and assimilation of $\mathrm{C}$ from these microheterotrophs by mussels were calculated from measured rates of defecation, respiration, excretion, and tissue incorporation. The proportion of available $\mathrm{C}$ ingested by $G$. demissa did not differ significantly among bacteria $(39 \%)$, heterotrophic flagellates $(58 \%)$, or the unicellular algae Isochrysis galbana $(66 \%)$, which was used as a reference diet. In contrast, $M$. edulis ingested a significantly lower proportion (19\%) of the small bacteria $(<1 \mu \mathrm{m}$ in diameter) than the larger ( 3 to $5 \mu \mathrm{m}$ diameter) heterotrophic flagellates $(58 \%)$. The efficiency with which $G$. demissa assimilated C from $I$. galbana $(77 \%)$ was significantly greater than that from either bacteria $(42 \%)$ or heterotrophic flagellates $(44 \%) . M$. edulis assimilated bacterial $\mathrm{C}$ with significantly lower efficiency $(21 \%)$ than $\mathrm{C}$ from heterotrophic flagellates $(62 \%)$. These results indicate that heterotrophic flagellates can contribute to the $C$ requirements of both $G$. demissa and $M$. edulis; however, only $G$. demissa is capable of assimilating a considerable amount of $\mathrm{C}$ from bacteria.
\end{abstract}

KEY WORDS: Mussel Bacteria Flagellate Assimilation Ingestion Carbon

\section{INTRODUCTION}

In marine environments phytoplankton are the dominant primary producers. Consequently, much of the research on the nutrition of suspension-feeding bivalve molluscs has concentrated on elucidating the availability of phytoplankton biomass. Numerous laboratory studies have documented the efficiency with which these cells can be ingested, digested and their $C$ assimilated (for reviews, see Webb \& Chu 1982, Bayne $\&$ Newell 1983, Langdon \& Newell 1996). Over the last 2 decades, it has been discovered that bacteria and

\footnotetext{
- Correspondence address: Patrick Center for Environmental Research, Academy of Natural Sciences, 1900 Benjamin Franklin Parkway, Philadelphia, Pennsylvania 19103, USA. E-mail: kreeger@acnatsci.org
}

bacterivorous flagellates within the microbial community cycle large amounts of $C$ fixed by both allochthonous and autochthonous producers (Pomeroy 1974 Azam et al. 1983, Sherr \& Sherr 1988, Reid et al. 1991). Compared with phytoplankton, we have a poor understanding of whether these microheterotrophs are of nutritional value to suspension-feeding bivalves.

Marine bacteria are predominantly less than $1 \mu \mathrm{m}$ in diameter, a size that is too small to be efficiently retained on the gill of most bivalves. Consequently, unattached bacteria meet only about $10 \%$ of the $C$ requirements of suspension-feeding bivalves (Langdon \& Newell 1990), except perhaps in eutrophic estuaries where bacterial abundances can exceed $1 \times$ $10^{7} \mathrm{ml}^{-1}$ (Crosby et al. 1990). However, the gill of the ribbed mussel Geukensia demissa (Dillwyn), which is a dominant organism in salt marshes of North America 
(Odum \& de la Cruz 1967, Jordan \& Valiela 1982, Bertness 1984), can retain small bacteria-sized particles with a greater efficiency (e.g. 18 to $30 \%$ ) than most other species of bivalves (Wright et al. 1982, Riisgård 1988, Kemp et al. 1990, Langdon \& Newell 1990, Newell \& Krambeck 1995). It has been postulated by Wright et al. (1982) and Langdon \& Newell (1990) that as a consequence of this adaptation, bacteria make an appreciable contribution to the diet of ribbed mussel populations. In contrast to bacteria, most nanoplanktonic heterotrophic flagellates are much larger ( 3 to $15 \mu \mathrm{m})$, a size that is efficiently captured by most bivalves (Riisgård 1988). In the only previous investigation of bivalves feeding on heterotrophic flagellates, Kemp et al. (1990) determined that $G$. demissa feeding on natural particle assemblages in a salt marsh in Georgia, USA, retained them and phytoplankton cells with similar efficiencies.

Laboratory mesocosm studies and field estimates of bacterial productivity and heterotrophic flagellate biomass by Newell \& Field (1983a) and Linley \& Newell (1984) indicate that microheterotrophs represent a significant source of $\mathrm{C}$ for bivalve suspension-feeders in the kelp beds off South Africa. Furthermore, the role of microheterotrophs in supplying the $\mathrm{N}$ demand of these bivalves may exceed their value as a $\mathrm{C}$ source (Newell \& Field 1983b). Studies that have examined microheterotroph digestibility by bivalves have mainly focused on bacteria (Birkbeck \& McHenery 1982, Crosby et al. 1990, Langdon \& Newell 1990, Chalermwat et al. 1991, Douillet 1993a, b). These studies generally indicate that bacteria can be digested with moderate efficiency (e.g. 20 to $50 \%$ ) by bivalves. Baldwin \& Newell $(1991,1995)$ determined that larvae of the eastern oyster Crassostrea virginica can ingest and assimilate with high efficiency all sizes of microheterotrophs from natural plankton assemblages collected from Chesapeake Bay. There is no information available, however, on the digestibility of bacterivorous nanoflagellates by adult bivalves, and hence the nutritional value of such microheterotrophs in the diet of bivalve molluscs is still largely unknown.

In this study we examined grazing and utilization of microheterotrophs by adults of 2 common species of bivalve mussels - the ribbed mussel Geukensia demissa and the blue mussel Mytilus edulis. We chose these species because they differ in their ability to retain particles smaller than $3 \mu \mathrm{m}$ in diameter (Riisgård 1988), and generally live in different habitats. Ribbed mussels inhabit salt marshes along the Atlantic coast of North America where there are high detritus inputs from emergent vascular plants, primarily Spartina alterniflora (Loisel.). Cellulosic detritus from such plants is highly refractory, and although it can be directly digested with low efficiency by $G$. demissa
(Kreeger et al. 1988, 1990), it has been postulated that bacteria and bacterivorous flagellates may make this detritus more readily available to higher organisms (Langdon \& Newell 1990). In contrast to $G$. demissa, $M$. edulis inhabits open coasts in North. America and Europe, where primary production results largely from phytoplankton

\section{MATERIALS AND METHODS}

Preparation of ${ }^{14} \mathrm{C}$-labeled diets. Microalgae: Isochrysis galbana (clone T-ISO) is widely used as a food for cultured suspension-feeding bivalves (Epifanio 1982, Webb \& Chu 1982), and in the present study, it was delivered to mussels as a standard food particle, against which heterotrophic diet utilization could be compared. I. galbana were enumerated with a hemacytometer, inoculated at 70000 cells $\mathrm{ml}^{-1}$, and uniformly labeled with ${ }^{14} \mathrm{C}$ in $\mathrm{f} / 2$ culture medium (Guillard \& Ryther 1962) containing $2.5 \mu \mathrm{Ci} \mathrm{NaH}\left[{ }^{14} \mathrm{C}\right] \mathrm{O}_{3}(58 \mathrm{mCi}$ $\mathrm{mmol}^{-1}$, ICN Biomedicals, Inc.). The culture was grown for $3 \mathrm{~d}$ under continuous light (700 lux) on a shaker table $(75 \mathrm{rpm})$. To calculate ${ }^{14} \mathrm{C}$-uptake, $2 \mathrm{ml}$ samples were each filtered through a $2.0 \mu \mathrm{m}$ polycarbonate membrane filter (Poretics Corp.), and these filters were then added to $6 \mathrm{ml}$ liquid scintillation cocktail (Universol ES, ICN Biomedicals, Inc.) for analysis (Packard Model $2200 \mathrm{CA}$ ) of ${ }^{14} \mathrm{C}$-activity. Before feeding to mussels, algal cells were separated from their culture medium by centrifugation $(100 \times \mathrm{g}, 10 \mathrm{~min})$ to remove dissolved ${ }^{14} \mathrm{C}$ (unused bicarbonate and algal metabolites) and were resuspended in $150 \mathrm{ml} 0.2 \mu \mathrm{m}$ filtered seawater. This washing procedure removed $>99.8 \%$ of dissolved organic $\left[{ }^{14} \mathrm{C}\right]$ carbon $\left(\left[{ }^{14} \mathrm{C}\right] \mathrm{DOC}\right)$ without damaging cell integrity, which was determined by comparing the similarity of algal cell concentrations before and after washing.

Bacteria: We used a cellulolytic strain of unidentified bacteria originally isolated from Canary Creek salt marsh, lower Delaware Bay, USA (Crosby et al. 1990, Langdon \& Newell 1990), purified twice on agar plates containing only cellulose as the $C$ source, and propagated in the laboratory for more than 8 yr on cellulosebased medium as described by Crosby et al. (1990). For our study, bacteria were routinely cultured at $20^{\circ} \mathrm{C}$ and 28 ppt salinity on glucose medium (Nagata \& Kirchman 1992), but with the exception that glucose concentrations were reduced from $10 \mathrm{mM}$ to $0.1 \mathrm{mM}$. Preliminary experiments indicated that bacteria grown in $10 \mathrm{mM}$ glucose were unnaturally large (e.g. 1 to $3 \mu \mathrm{m}$ ); whereas, bacteria cultured in $0.1 \mathrm{mM}$ glucose retained small cell sizes $(<1 \mu \mathrm{m})$ typical of estuarine bacteria [verified by microscopic measurement of acridine orange stained cells; Hobbie et al. (1977) but $0.05 \%$ 
acridine orange, $100 \mathrm{~W}$ mercury lamp excitation, examined at $1000 \times]$.

Bacteria were labeled with ${ }^{14} \mathrm{C}$ for $5 \mathrm{~d}$. Three 11 flasks, each containing $400 \mathrm{ml}$ glucose-free, sterile medium were inoculated with $1 \times 10^{7}$ cells $\mathrm{ml}^{-1}$. A mixture of $98 \%$ non-labeled glucose and $\left.2 \% l^{14} \mathrm{C}\right)$ glucose [ICN 11048; D-glucose (U- ${ }^{14} \mathrm{C}$ ), $43.7 \mu \mathrm{Ci} \mathrm{mg}^{-1}$ ] was added to give a final glucose concentration of $0.1 \mathrm{mM}$. Flasks were mixed by swirling 3 times per day. Growth of bacteria was monitored by daily filtering $2 \mathrm{ml} \mathrm{sam}$ ples onto $0.2 \mu \mathrm{m}$ pore size, black polycarbonate membrane filters (Poretics Corp.) for counting. Bacterial cell sizes were measured microscopically. To calculate ${ }^{14} \mathrm{C}$ uptake by bacteria, a $2 \mathrm{ml}$ sample was removed daily from each flask, filtered onto a $0.2 \mu \mathrm{m}$ membrane filter, and the filter was counted for ${ }^{14} \mathrm{C}$-activity. Cellular specific activities were calculated each day by dividing the ${ }^{14} \mathrm{C}$ taken up by bacteria by the cell number in each flask. Bacteria were assumed to be close to uniform labeling when cellular specific activities no longer increased on successive days.

At the end of the ${ }^{14} \mathrm{C}$-labeling period, contents of the 3 flasks were pooled (i.e. $1.2 \mathrm{l}$ ), and $60 \mathrm{ml}$ was fed to each mussel as described below. The final bacteria concentration in each $500 \mathrm{ml}$ feeding vessel was $3.5 \times 10^{6}$ cells $\mathrm{ml}^{-1}$ with each mussel being provided $0.19 \mu \mathrm{Ci}{ }^{14} \mathrm{C}$ and $1.75 \times 10^{9}$ cells of $\left[{ }^{14} \mathrm{C}\right]$ bacteria. The remaining bacteria culture was filtered through a $0.2 \mu \mathrm{m}$ membrane filter. As a control for the uptake of $\left[{ }^{14} \mathrm{CJDOC}\right.$ from the bacteria culture media by mussels, $500 \mathrm{ml}$ of this filtrate was delivered to additional mussels.

Bacteria/flagellate assemblage: Three species of estuarine heterotrophic nanoflagellates, Bodo parvulis, Paraphysomonas bandaiensis, and Cafeteria sp., were obtained from D. A. Caron (Woods Hole Oceanographic Institute, Massachusetts, USA). Nanoflagellates were maintained on rice grains in filtered and autoclaved seawater at $20^{\circ} \mathrm{C}$ and $28 \mathrm{ppt}$ salinity, amended with $0.1 \mathrm{ml} \mathrm{l}^{-1}$ metal-chelator stock solution (Guillard 1975). When fed solely on our cultured strain of cellulolytic bacteria $\left(10^{7}\right.$ bacterial cells $\left.\mathrm{ml}^{-1} \mathrm{~d}^{-1}\right)$, nanoflagellates typically underwent $>1$ division $\mathrm{d}^{-1}$.

Heterotrophic flagellates were radiolabeled by culturing them on ${ }^{14} \mathrm{C}$-labeled bacteria for $3 \mathrm{~d}$. In addition to the 3 flasks of bacteria that were ${ }^{14} \mathrm{C}$-labeled as food for mussels (see above), 6 additional flasks of bacteria were labeled similarly, but were then inoculated with the 3 species of flagellates in duplicate with 3000 flagellate cells $\mathrm{ml}^{-1} 2 \mathrm{~d}$ after the addition of ${ }^{14} \mathrm{C}$. Each day following inoculation, $5 \mathrm{ml}$ was removed from each flask for flagellate and bacteria cell counts. Bacterial abundances were determined as described above by epifluorescent counting. For flagellates, samples were preserved with glutaraldehyde (final conc. $0.5 \%$ ), stained with 3-6-dianinoacridine hemisulfate (proflavin) for $1 \mathrm{~min}$ (final conc. $4.5 \mu \mathrm{g} \mathrm{ml}^{-1}$ ), filtered onto a $2.0 \mu \mathrm{m}$ pore size black membrane filter (Poretics Corp.), and examined microscopically (modification of technique of Haas 1982). A second $5 \mathrm{ml}$ aliquot was similarly filtered each day to determine the proportion of total culture ${ }^{14} \mathrm{C}$ incorporated by either flagellates (2.0 $\mu \mathrm{m}$ filter) or bacteria $(0.2 \mu \mathrm{m}$ filter). Just before feeding to mussels, the 2 flasks of each flagellate/bacteria assemblage were combined. A $60 \mathrm{ml}$ volume of each mixed flagellate/bacteria assemblage was provided as food directly to mussels as described below. Final concentrations of flagellates in feeding vessels were approximately 7200 Bodo parvulis ml-1, 5400 Paraphysomonas bandaiensis $\mathrm{ml}^{-1}$, and 3600 Cafeteria $\mathrm{sp} . \mathrm{ml}^{-1}$. The remaining flagellate/bacteria cultures were filtered through $0.2 \mu \mathrm{m}$ membrane filters. As controls for $\left[{ }^{14} \mathrm{C}\right] \mathrm{DOC}$ uptake, identical volumes of these filtrates were delivered to additional mussels.

Mussel collection and acclimation. Thirty adult Geukensia demissa and 10 adult Mytilus edulis were collected in September 1994 from the salt marsh and ocean breakwater, respectively, at Canary Creek. Mussel sizes (shell lengths, range 41.9 to $58.9 \mathrm{~mm}$; dry tissue weights, 272 to $1304 \mathrm{mg}$ ) did not differ significantly between species. Mussels were held in the laboratory at the field ambient water temperature of $21^{\circ} \mathrm{C}$ under intertidal conditions (6 h submerged: $6 \mathrm{~h}$ air exposure, coinciding with the ambient tidal cycle) to avoid disrupting their natural feeding and digestive cycles. When submerged, mussels were held in $120 \mathrm{l}$ marsh water collected directly from the marsh creek to maintain natural food availability. Experiments were initiated $12 \mathrm{~h}$ after the mussels were collected to minimize any physiological adjustments to laboratory conditions.

Delivery of ${ }^{14} \mathrm{C}$-labeled diets. Mussels were submerged after 6 h of aerial exposure and fed ${ }^{14} \mathrm{C}$-labeled diets using a 'pulse-chase' approach, in which the ${ }^{14} \mathrm{C}$-labeled diets were delivered during a $2 \mathrm{~h}$ pulse, followed by an extended depuration period. Based on previous reports of the gut residence time and $C$ budgets of these mussels (Kreeger et al. 1988, 1996, Hawkins et al. 1990), the 2 h duration of the pulse was calculated to allow mussels sufficient time to ingest a substantial amount of the labeled diets, but not enough time to either defecate, excrete or respire the ingested label. The experimental treatments and number of replicates for each diet and mussel species are presented in Table 1.

At the start of the feeding period, mussels, all of which had been exposed to air for $6 \mathrm{~h}$, were transferred to individual $1 \mathrm{l}$ vessels containing $500 \mathrm{ml} 0.2 \mu \mathrm{m}$ filtered, lightly aerated seawater, to which was added one of the ${ }^{14} \mathrm{C}$-labeled diets (dosages given above) in a 
Table 1. List of ${ }^{14} \mathrm{C}$-labeled diets delivered to Geukensia demissa and Mytilus edulis. Replication refers to cell size measurements

\begin{tabular}{|c|c|c|c|}
\hline Mussel species & ${ }^{14} \mathrm{C}$-labeled diet & Mean \pm SD cell diameter $(\mu m)$ & Replication \\
\hline \multirow[t]{8}{*}{ Geukensia demissa } & Cellulolytic bacteria & $0.8 \pm 0.26$ & 50 \\
\hline & Flagellate/bacteria assemblages: & & \\
\hline & Bodo parvulis & $4.4 \pm 0.36$ & 10 \\
\hline & Paraphysomonas bandaiensis & $4.1 \pm 0.22$ & 10 \\
\hline & Cafeteria sp. & $3.5 \pm 0.29$ & 10 \\
\hline & Microalgae (Isochrysis galbana clone T-ISO) & 3 to 5 & 4 \\
\hline & DOC from bacteria diet & - & - \\
\hline & DOC from 3 flagellate/bacteria diets & - & - \\
\hline \multirow[t]{3}{*}{ Mytilus edulis } & Cellulolytic bacteria & $0.8 \pm 0.26$ & 50 \\
\hline & Flagellate/bacteria assemblage & & \\
\hline & Cafeteria sp. & $3.5 \pm 0.29$ & 10 \\
\hline
\end{tabular}

mixture of simulated natural seston. Simulated seston, which comprised more than $75 \%$ of the total diet dry weight, was used as a 'background' diet to prevent mussels from physiologically responding to a change in diet quality and/or quantity associated with any of the test diets. This simulated seston consisted of a $1: 1$ DW:DW mixture of fine marsh mud screened through a $43 \mu \mathrm{m}$ sieve, and Isochrysis galbana, added to yield $3 \mathrm{mg}$ total DW $\mathrm{l}^{-1}$. The background diet was sterilized ( $2 \mathrm{~h}$, cobalt gamma irradiation) just before the experiment to prevent recycling by the microorganisms of ${ }^{14} \mathrm{C}$ excreted by the mussels.

Depuration protocol. Following the $2 \mathrm{~h}$ labeling period, mussels were transferred to a second set of 11 vessels to depurate for the remaining $4 \mathrm{~h}$ of the submergence period. Depuration vessels contained $800 \mathrm{ml}$ $0.2 \mu \mathrm{m}$ filtered seawater, to which simulated seston was added at hourly intervals to yield a final concentration of $3 \mathrm{mg} \mathrm{l}^{-1}$. Mussels were then held in air for $6 \mathrm{~h}$ in individual sealed glass jars to measure aerial ${ }^{14} \mathrm{CO}_{2}$ respiration (see below). During the final $6 \mathrm{~h}$ of the $18 \mathrm{~h}$ experiment, mussels were submerged and fed simulated natural seston as described above.

Quantification of ${ }^{14} \mathrm{C}$-budget. ${ }^{14} \mathrm{C}$-activity of diets: The actual ${ }^{14} \mathrm{C}$-activity present in each feeding beaker was determined at the start of the experiment just before mussels were added by counting a $2 \mathrm{ml} \mathrm{sample}$ of the mixed water. For diets having mixed assemblages of bacteria, heterotrophic flagellates, and DOC, the dietary ${ }^{i 4} \mathrm{C}$-activity assoclated with each constituent was calculated by multiplying total beaker ${ }^{14} \mathrm{C}$-activities by the expected proportion of assemblage ${ }^{14} \mathrm{C}$ in a particular constituent, which was measured prior to the experiment by fractional filtration (see above).

Defecation of ${ }^{14} \mathrm{C}$ : At the end of each submergence period (i.e. at $6 \mathrm{~h}$ and $18 \mathrm{~h}$ ), mussels were removed from depuration vessels, and the feces in each beaker was collected on a Whatman GF/C filter. Individual fil- ters were added to $6 \mathrm{ml}$ scintillation cocktail and counted for ${ }^{14} \mathrm{C}$-activity. Total ${ }^{14} \mathrm{C}$-defecation by each mussel was then calculated by summing ${ }^{14} \mathrm{C}$-activities in feces from both submergence periods.

Respiration and excretion of ${ }^{14} \mathrm{C}$ : Seawater used to depurate mussels contained respired ${ }^{14} \mathrm{CO}_{2}$ and possibly excreted $\left[{ }^{14} \mathrm{C}\right]$ DOC. After feces had been filtered from depuration water, the amount of respired ${ }^{14} \mathrm{C}$ in a $5 \mathrm{ml}$ aliquot of each filtrate was calculated as the difference between the total ${ }^{14} \mathrm{C}$-activity in the aliquot and the amount of ${ }^{14} \mathrm{C}$ remaining after the $\mathrm{pH}$ had been lowered to $<1$ with $0.5 \mathrm{ml} 2 \mathrm{M} \mathrm{HCl}$ to volatilize all ${ }^{14} \mathrm{CO}_{2}$. Any ${ }^{14} \mathrm{C}$ remaining after acidification was considered to be excreted $\left[{ }^{14} \mathrm{C}\right] \mathrm{DOC}$. Respired and excreted ${ }^{14} \mathrm{C}$-activities in the aliquot were then corrected for the total volume of depuration water. During the $6 \mathrm{~h}$ period of air exposure, mussels were held in sealed jars containing $\mathrm{NaOH}(5 \mathrm{ml} 25 \% \mathrm{w} / \mathrm{v}$ ) traps for quantifying ${ }^{14} \mathrm{CO}_{2}$ production (Kreeger \& Langdon 1994). Total ${ }^{14} \mathrm{C}$-respiration was calculated by summing ${ }^{14} \mathrm{CO}_{2}$ production from periods of submergence and air exposure.

Tissue incorporation of ${ }^{14} \mathrm{C}$ : Following depuration, mussel tissues were dissected, homogenized (Polytron, Brinkman, Inc.), and diluted to a known volume with distilled water. A $2 \mathrm{ml}$ aliquot of each mussel tissue homogenate was added to a pre-weighed pan, dried at $60^{\circ} \mathrm{C}$ for $2 \mathrm{~d}$, and re-weighed to calculate dry tissue weight. Two ml of each homogenate was also added to 4 nil LSC anul counted for ${ }^{14} \mathrm{C}$-activity, cnabling the total ${ }^{14} \mathrm{C}$-activity of the mussel tissue (i.e. ${ }^{14} \mathrm{C}$-incorporation) to be calculated.

Calculation of dietary utilization. Ingestion (I) of the ${ }^{14} \mathrm{C}$-labeled diet by each mussel was calculated by summing measured ${ }^{14} \mathrm{C}$-activities of the 4 components of its ${ }^{14} \mathrm{C}$-budget; defecation $(F)$, excretion $(U)$, respiration $(R)$, and incorporation $(G)$, as given in Eq. (1):

$$
I=F+U+R+G
$$


To compare the mussel's relative ability to ingest the different particles, we also calculated the proportion of available ${ }^{14} \mathrm{C}$ in the feeding chamber that was ingested by each individual:

$$
\text { Proportion ingested }=(\text { I/Available }) \times 100 \%
$$

We define assimilation as material that is unequivocally utilized by the mussels. While it is possible that a portion of fecal and excreted $C$ can be post-metabolic losses (e.g. mucus, amino acids; see Hawkins \& Bayne 1985, Hawkins et al. 1990), we conservatively calculated ${ }^{14} \mathrm{C}$-assimilation $(A)$ as the sum of ${ }^{14} \mathrm{C}$-respiration and ${ }^{14} \mathrm{C}$-incorporation:

$$
A=R+G
$$

To compare the mussel's relative ability to digest and assimilate $\mathrm{C}$ from the different dietary particles, we calculated the assimilation efficiency as the proportion of ingested ${ }^{14} \mathrm{C}$ that was assimilated;

$$
\text { Assimilation efficiency }=(A / I) \times 100 \%
$$

Finally, to estimate the mussel's relative ability to ingest and digest each diet, we calculated a 'percent utilized' as the proportion of available ${ }^{14} \mathrm{C}$ in the feeding chamber that was assimilated;

$$
\text { Percent utilized }=(\mathrm{A} / \text { Available }) \times 100 \%
$$

The reference diet of Isochrysis galbana contained only negligible $\left[{ }^{14} \mathrm{C}\right] \mathrm{DOC}$, and so the ability of Geukensia demissa to utilize I. galbana was summarized by the calculations given above. However, heterotrophic diets of bacteria and the mixed assemblage of bacteria and flagellates contained between 11 and $36 \%\left[{ }^{14} \mathrm{C}\right] \mathrm{DOC}$, and the mussel's ability to utilize this DOC needed to be determined and, if necessary, subtracted from their calculated utilization of the ${ }^{14} \mathrm{C}$ labeled particulates. Four control diets containing only $\left[{ }^{14} \mathrm{C}\right] \mathrm{DOC}$ were included in the experimental design to be fed only to $G$. demissa. The $\left[{ }^{14} \mathrm{CJDOC}\right.$ for these 4 diets consisted of the filtrate from the 4 respective heterotrophic diets; $\left[{ }^{14} \mathrm{C}\right]$ bacteria, $\left[{ }^{14} \mathrm{C}\right]$-labeled Bodo parvulis and bacteria, $\left[{ }^{14} \mathrm{C}\right.$-labeled Paraphysomonas bandaiensis and bacteria, and $\left[{ }^{14} \mathrm{C}\right]$-labeled Cafeteria sp. and bacteria. Mean ${ }^{14} \mathrm{C}$-activities associated with each component of the ${ }^{14} \mathrm{C}$-budget (i.e. available, $F, U, R, G$ ) that resulted from these controls were subtracted from the ${ }^{14} \mathrm{C}$-activities of respective components of the ${ }^{14} \mathrm{C}$-budget of mussels fed the complete heterotroph/DOC diet. These corrections were applied before calculation of the proportion of each diet ingested, its assimilation efficiency, and its percent utilized.

Since it was not possible to physically separate heterotrophic flagellates from the $\left[{ }^{14} \mathrm{C}\right]$ bacteria used to feed and label them, our flagellate diets consisted of a mixed assemblage of ${ }^{14} \mathrm{C}$-labeled bacteria and flagellates. The ${ }^{14} \mathrm{C}$-budget was initially summarized as described above for the mixed assemblage. Utilization of flagellates by mussels was then separated from bacteria utilization in these mixed assemblages by subtraction of the proportion of the total ${ }^{14} \mathrm{C}$-budget that could have been associated with $\left[{ }^{14} \mathrm{C}\right]$ bacteria utilization, as measured in treatments where mussels were fed only $\left[{ }^{14} \mathrm{C}\right]$ bacteria. We assumed that bacteria were ingested and assimilated by mussels similarly between the diet of bacteria and the mixed assemblage diet because bacteria were always of similar size (mean \pm $\mathrm{SD}=0.8 \pm 0.26 \mu \mathrm{m})$. This approach also required the assumption that the retention efficiency of mussels for small particles was similar between the 2 diets; i.e. that they did not decrease their retention efficiency for bacteria when in the presence of larger heterotrophic flagellates, as has been found for oysters (Palmer \& Williams 1980). If mussels did respond positively to the heterotrophic flagellates, then our approach would underestimate flagellate ingestion and utilization. Such a behavioral response was rendered unlikely in our experimental protocol because all ${ }^{14} \mathrm{C}$-labeled diets were delivered to mussels as supplements $<25 \%$ $w / w)$ to a common non-labeled mixture of silt and microalgae, and hence, there were similar overall amounts of small and large particles available in the different diets.

Calculation of flagellate utilization by mussels first required multiplication of the proportion of available $\left[{ }^{14} \mathrm{C}\right.$ )bacteria ingested (determined in the bacteria treatment) by the available dietary $\left[{ }^{14} \mathrm{C}\right]$ bacteria in the mixed assemblage (determined above) to estimate the mussel's ingestion of $\left[{ }^{14} \mathrm{C}\right]$ bacteria from the mixed assemblage. The difference between total ${ }^{14} \mathrm{C}$-ingestion and estimated $\left[{ }^{14} \mathrm{C}\right]$ bacteria ingestion was assumed to be $\left[{ }^{14} \mathrm{C}\right]$ flagellate ingestion. Second, the mussel's assimilation efficiency for $\left[{ }^{14} \mathrm{C}\right]$ bacteria (determined in the bacteria treatment) was multiplied by the estimated $\left[{ }^{14} \mathrm{C}\right]$ bacteria ingested from the mixed assemblage to estimate assimilation of $\left[{ }^{14} \mathrm{C}\right]$ bacteria from the mixed assemblage. The difference between the mussel's total ${ }^{14} \mathrm{C}$-assimilation and estimated $\left[{ }^{14} \mathrm{C}\right]$ bacteria assimilation represented $\left[{ }^{14} \mathrm{C}\right]$ heterotrophic flagellate assimilation.

\section{RESULTS}

\section{Diet cultures}

Microalgae. Isochrysis galbana delivered to Geukensia demissa had ${ }^{14} \mathrm{C}$-activities of $11.4 \mathrm{dpm}$ $(1000 \text { cells })^{-1}$, and more than 90000 dpm were provided to each mussel. 
Bacteria. At the end of the labeling period, $>99 \%$ of the ${ }^{14} \mathrm{C}$-activity in the bacteria culture was present in bacterial biomass. Cell specific activities remained at approximately $90 \mathrm{dpm}\left[10^{6} \text { cells }\right]^{-1}$ atter Day 2, suggesting that bacteria were uniformly labeled with ${ }^{14} \mathrm{C}$. However, bacteria cell concentrations increased from $1 \times 10^{7}$ cells ml $\mathrm{m}^{-1}$ to only $2.92 \times 10^{7}$ cells $\mathrm{ml}^{-1}$ during the $5 \mathrm{~d}{ }^{14} \mathrm{C}$-labeling period. Further growth was inhibited by depletion of glucose in the culture medium. Since bacterial cells did not double multiple times, it was not possible to know for certain if they were completely uniformly labeled. If bacteria were not uniformly labeled, the mussel's ability to assimilate bacterial $\mathrm{C}$ could have been overestimated because ${ }^{14} \mathrm{C}$ might have been more prevalent in readily digestible components of bacterial biomass. To ronfirm the results reported in this study, we ${ }^{14} \mathrm{C}$-labeled a second culture of the same species of bacteria until cell concentrations doubled more than 3 times. When fed to Gcukensia demissa, these bacteria were assimilated with greater efficiency (mean 67.3\%, SD 5.2\%, $\mathrm{n}=7$ ), not lower efficiency, compared with mussels fed the growthlimited bacteria in this study $(41.7 \%$ assimilation efficiency, see below). Therefore, we believe that the bacteria in the present study were ${ }^{14} \mathrm{C}$-labeled with sufficient uniformity to determine their food value to mussels.

Bacteria/flagellate assemblage. During the $3 \mathrm{~d}$ culture period after inoculation of heterotrophic flagellates into $\left[{ }^{14} \mathrm{C}\right.$ bacteria cultures, flagellate cell concentrations increased from $3000 \mathrm{ml}^{-1}$ to an average $(\mathrm{n}=6)$ of $44900 \mathrm{ml}^{-1}$ (3.9 doublings) and mean bacteria cell concentrations remained similar (initial $=6.88 \times 10^{6}$ $\mathrm{ml}^{-1}$, final $\left.=6.65 \times 10^{6} \mathrm{ml}^{-1}\right)$. Cell sizes $($ mean $0.8 \mu \mathrm{m}$, $\mathrm{SD} 0.26 \mu \mathrm{m}, \mathrm{n}=50$ ) and aggregation of bacteria in these assemblages did not differ from that in bacteria cultures without flagellates (examined by epifluorescent microscopy). At the time the 3 different (Bodo parvulis, Paraphysomonas bandaiensis, and Cafeteria sp.) mixed assemblages were delivered to mussels, an average $31.0 \%( \pm 4.9 \% \mathrm{SD}, \mathrm{n}=6)$ of ${ }^{14} \mathrm{C}$ was incorporated by flagellates and $19.0 \%( \pm 2.2 \% \mathrm{SD}, \mathrm{n}=6)$ was present as $\left[{ }^{14} \mathrm{C}\right.$ lbacteria. Bacterial cell specific activities in mixed flagellate/bacteria assemblages were similar [range 65 to $108 \mathrm{dpm}\left(10^{6} \text { cells }\right)^{-1}$ ] to those measured in bacteria cultures (see above). Flagellate cell specific activities averaged $78 \mathrm{dpm}\left(10^{3} \text { cells }\right)^{-1}$ at the end of the $3 \mathrm{~d}$ culture period. Mussels fed the mixed assemblage of $B$. parvulis and bacteria received a total of $266400 \mathrm{dpm}$, distributed as $34.8 \%$ non-incorporated $\left[{ }^{14} \mathrm{C}\right] \mathrm{DOC}, 32.8 \%\left[{ }^{14} \mathrm{C}\right]$ bacteria, and $32.4 \%{ }^{14} \mathrm{C}$-labeled $B$. parvulis. Mussels fed ${ }^{14} \mathrm{C}$-labeled $P$. bandaiensis and bacteria received a calculated $199800 \mathrm{dpm}$ as $36.4 \%$ $\left[{ }^{14} \mathrm{C}\right] \mathrm{DOC}, 21.1 \%\left[{ }^{14} \mathrm{C}\right.$ bacteria and $42.5 \%{ }^{14} \mathrm{C}$-labeled $P$. bandaiensis. Mussels fed ${ }^{14} \mathrm{C}$-labeled Cafeteria sp. and bacteria received a calculated $244200 \mathrm{dpm}$ as $18.3 \%\left[{ }^{14} \mathrm{C}\right] D O C, 26.6 \%\left[{ }^{14} \mathrm{C}\right]$ bacteria and $55.1 \%{ }^{14} \mathrm{C}$ labeled Cafeteria sp.

\section{Utilization of ${ }^{14} \mathrm{C}$-labeled diets}

A negligible amount of $\left[{ }^{14} \mathrm{C}\right.$ JDOC from $\left[{ }^{14} \mathrm{C}\right]$ heterotroph cultures was taken up and utilized by mussels. For example, ${ }^{14} \mathrm{C}$-incorporation from $\left[{ }^{14} \mathrm{C}\right] \mathrm{DOC}$ heterotroph controls represented only 1.5 to $3.5 \%$ of comparable ${ }^{14} \mathrm{C}$-incorporation from the respective $\left[{ }^{14} \mathrm{C}\right]$ heterotroph particle diets. The proportion of each diet ingested and the assimilation efficiency were corrected for uptake of $\left[{ }^{14} \mathrm{C}\right]$ DOC, and these results are presented for microalgae (Table 2), bacteria (Table 2), and heterotrophic flagellates (Table 3 ). To ensure normality of these proportional data, they were arcsine transformed for statistical analyses (Sokal \& Rohlf 1981). Comparisons among dietary treatments were performed by ANOVA and Tukey's multiple range analyses using the software package Statgraphics (V. 6.0). The proportion ingested, assimilation efficiency and percent utilization for the 3 different species of heterotrophic flagellates (Bodo parvulis, Paraphysomonas bandaiensis, and Cafeteria sp.) by Geukensia demissa were not significantly different (ANOVA, p > $0.05)$; therefore, we pooled these data in the following comparisons of the mussel's utilization of the various diets.

A substantial proportion of the reference diet of Isochrysis galbana was ingested by Geukensia demissa (Table 2). Heterotrophic flagellates were also readily ingested by both $G$. demissa and Mytilus edulis (Table 3). Compared to its ingestion of heterotrophic flagellates, however, $M$. edulis ingested a significantly (Tukey's multiple range analysis, $\mathrm{p}<0.05$ ) lower proportion of dietary bacteria, whereas the proportion of dietary bacteria ingested by $G$. demissa did not significantly differ from that for either heterotrophic flagellates or I. galbana.

Assimilation efficiencies of Geukensia demissa were significantly greater $(p<0.05)$ when the diet consisted of microalgae compared to either heterotrophic flagellates or bacteria (Tables $2 \& 3$ ). The assimilation efficlency by Mytius eauils for $C$ from liayelidies was not significantly $(p>0.05)$ different from that by $G$. demissa, but was significantly greater $(p<0.05)$ than its ability to assimilate bacteria (Tables $2 \& 3$ ). When our measures of $\mathrm{C}$ ingestion and assimilation were integrated to calculate the percent utilized (i.e. amount of available dietary material assimilated), there was significant heterogeneity (ANOVA, p < 0.0001) among the 5 diets (Fig 1). As expected, the greatest utilization occurred when $G$. demissa was fed Isochrysis galbana 
Table 2. Calculation of the proportion ingested and assimilation efficiency for Geukensia demissa fed on ${ }^{14} \mathrm{C}-\mathrm{labeled}$ bacteria (unidentified cellulolytic marsh isolate) and the reference species of microalgae (Isochrysis galbana clone T-ISO), and for Mytilus edulis fed ${ }^{14} \mathrm{C}$-labeled bacteria. Values are corrected for the uptake of $\left[{ }^{14} \mathrm{C}\right] \mathrm{DOC}$ (see text for details)

\begin{tabular}{|c|c|c|c|c|c|c|c|}
\hline Mussel species & Diet & Replicate & $\begin{array}{l}\text { Available } \\
\text { dietary }{ }^{14} \mathrm{C} \\
\left(\text { dpm } \times 10^{1}\right)\end{array}$ & $\begin{array}{c}\text { Ingested } \\
{ }^{14} \mathrm{C} \\
\left(\mathrm{dpm} \times 10^{3}\right)\end{array}$ & $\begin{array}{c}\text { Proportion } \\
\text { ingested } \\
(\cdots)\end{array}$ & $\begin{array}{l}\text { Assimilated } \\
{ }^{H} \mathrm{C} \\
\left(\mathrm{dpm} \times 10^{4}\right)\end{array}$ & $\begin{array}{c}\text { Assimilation } \\
\text { efficiency } \\
(\%)\end{array}$ \\
\hline \multirow[t]{12}{*}{ Geukensia demissa } & Bacteria & 1 & 1174 & 619 & 52.7 & 228 & 36.9 \\
\hline & & 2 & 653 & 218 & 33.4 & 148 & 67.8 \\
\hline & & 3 & 981 & 402 & 41.0 & 138 & 34.3 \\
\hline & & 4 & 1011 & 282 & 27.9 & 81 & 28.6 \\
\hline & \multirow{2}{*}{\multicolumn{3}{|c|}{$\begin{array}{r}\text { Mean } \\
\text { SD }\end{array}$}} & \multirow{2}{*}{\multicolumn{3}{|c|}{$\begin{array}{r}38.6 \\
6.4\end{array}$}} & 41.7 \\
\hline & & & & & & & 10.7 \\
\hline & \multirow[t]{6}{*}{ Algae } & 1 & 121 & 81.2 & 66.9 & 60.6 & 74.6 \\
\hline & & 2 & 109 & 60.8 & 55.7 & 45.8 & 75.3 \\
\hline & & 3 & 135 & 92.5 & 68.7 & 73.9 & 80.0 \\
\hline & & 4 & 137 & 99.3 & 72.4 & 76.3 & 76.8 \\
\hline & & Med & & & 66.1 & & 76.7 \\
\hline & & & & & 5.2 & & 2.1 \\
\hline \multirow[t]{5}{*}{ Mytilus edulis } & \multirow[t]{5}{*}{ Bacteria } & 1 & 551 & 56.4 & 10.3 & 8.2 & 14.5 \\
\hline & & 2 & 379 & 99.7 & 26.3 & 22.4 & 22.5 \\
\hline & & 3 & 733 & 172.5 & 23.5 & 47.6 & 27.6 \\
\hline & & Med & & & 19.5 & & 21.3 \\
\hline & & & & & 4.9 & & 3.6 \\
\hline
\end{tabular}

Table 3. Estimation of the proportion ingested and assimilation efficiency for heterotrophic flagellates (Bodo parvulis, $P_{a r a-}$ physomonas bandaiensis, Cafeteria sp.) fed to Geukensia demissa and Mytilus edulis as a ${ }^{14} \mathrm{C}$-labeled assemblage of flagellates and bacteria. Values are corrected for the uptake of $\left[{ }^{14} \mathrm{C}\right] \mathrm{DOC}$ (see text for details)

\begin{tabular}{|c|c|c|c|c|c|c|c|c|}
\hline \multirow[t]{2}{*}{ Mussel species } & \multirow[t]{2}{*}{ Diet } & \multirow{2}{*}{$\begin{array}{l}\text { Flagellate } \\
\text { dietary }{ }^{14} \mathrm{C} \\
\left(\mathrm{dpm} \times 10^{3}\right)\end{array}$} & \multicolumn{2}{|c|}{$\begin{array}{l}{ }^{14} \mathrm{C} \text { ingested } \\
\left(\mathrm{dpm} \times 10^{3}\right)\end{array}$} & \multirow{2}{*}{$\begin{array}{c}\text { Proportion } \\
\text { ingested } \\
(\%)\end{array}$} & \multicolumn{2}{|c|}{$\begin{array}{c}{ }^{14} \mathrm{C} \text { assimilated } \\
\left(\mathrm{dpm} \times 10^{3}\right)\end{array}$} & \multirow{2}{*}{$\begin{array}{c}\text { Assimilation } \\
\text { efficiency } \\
(\%)\end{array}$} \\
\hline & & & $\begin{array}{c}\text { From } \\
\text { bacteria }\end{array}$ & $\begin{array}{l}\text { From } \\
\text { flagellates }\end{array}$ & & $\begin{array}{c}\text { From } \\
\text { bacteria }\end{array}$ & $\begin{array}{l}\text { From } \\
\text { flagellates }\end{array}$ & \\
\hline \multirow[t]{10}{*}{ Geukensia demissa } & B. parvulis & 131 & 51.1 & 111 & 85.2 & 21.3 & 44.7 & 40.2 \\
\hline & B. parvulis & 156 & 61.1 & 108 & 69.4 & 25.5 & 45.4 & 41.9 \\
\hline & B. parvulis & 178 & 70.2 & 102 & 57.3 & 29.3 & 45.3 & 44.4 \\
\hline & P. bandaiensis & 160 & 30.6 & 31 & 19.6 & 12.8 & 19.6 & 62.5 \\
\hline & P bandaiensis & 144 & 27.5 & 85 & 59.3 & 11.5 & 31.9 & 37.3 \\
\hline & Cafeteria sp. & 356 & 66.4 & 221 & 61.9 & 27.7 & 89.4 & 40.5 \\
\hline & Cafeteria sp. & 496 & 92.4 & 432 & 87.0 & 38.6 & 216.4 & 50.1 \\
\hline & Cafeteria sp. & 230 & 42.8 & 49 & 21.5 & 17.9 & 17.8 & 36.1 \\
\hline & $\mathrm{Me}$ & ean & & & 58.2 & & & 44.1 \\
\hline & & $\mathrm{SD}$ & & & 18.6 & & & 5.3 \\
\hline \multirow[t]{5}{*}{ Mytilus edulis } & Cafeteria sp. & 130 & 18.0 & 69 & 53.0 & 3.8 & 40.1 & 58.3 \\
\hline & Cafeteria sp. & 144 & 16.3 & 38 & 26.2 & 3.5 & 27.3 & 72.3 \\
\hline & Cafeteria sp. & 138 & 24.4 & 124 & 89.8 & 5.2 & 68.4 & 55.4 \\
\hline & $\mathrm{Me}$ & ean & & & 58.0 & & & 62.2 \\
\hline & & $\mathrm{SD}$ & & & 24.0 & & & 6.5 \\
\hline
\end{tabular}

$(50.6 \%)$. Although significantly $(\mathrm{p}<0.05)$ lower than that for microalgae, $G$. demissa assimilated similar proportions of available ${ }^{14} \mathrm{C}$-labeled heterotrophic flagellates $(24.0 \%)$ and bacteria $(15.6 \%)$. M. edulis also assimilated a substantial proportion of dietary $\mathrm{C}$ from heterotrophic flagellates $(32.6 \%)$ but utilized significantly less $(4.3 \%) \mathrm{C}$ from bacteria.

\section{DISCUSSION}

The suspension-feeding mussel Geukensia demissa was adept at ingesting and assimilating $C$ from both heterotrophic flagellates and bacteria. Heterotrophic flagellates, but not bacteria, were ingested and assimilated well by the mussel Mytilus edulis. Although 


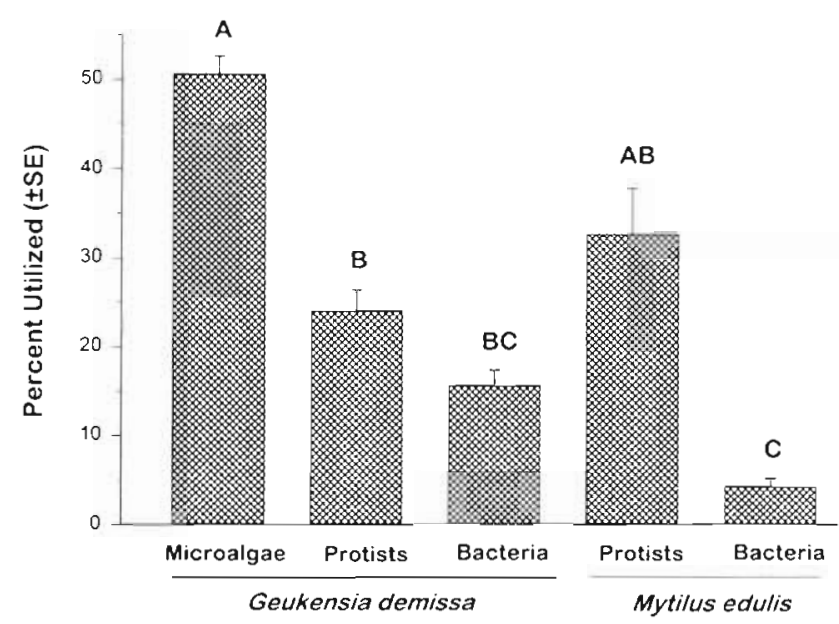

Fig. 1. Percent utilizated (i.e. proportion of dietary particulate carbon that was assimilated) for microalgae, heterotrophic flagellates and bacteria by Geukensia demissa and Mytilus edulis. Significant ( $p<0.05$, Tukey's multiple range analysis) differences are denoted as different letters above bars

heterotrophic microorganisms were not used as readily as a reference species of microalgae, our data nonetheless suggest that microheterotrophs could be a significant component in the natural diet of suspension-feeding bivalves, depending on the relative abundance in the seston of heterotrophic and autotrophic microorganisms. Particularly for $G$. demissa, which lives high in the intertidal zone of detritus-dominated salt marshes of the eastern USA, the dietary abundance of phytoplankton can be low and variable compared with heterotrophic members of the decomposer food web (Langdon \& Newell 1990). In these systems, Langdon \& Newell (1990) postulated that detrital $C$ from vascular plants is mainly utilized by detritivorous bacteria that are in turn grazed by bacterivorous flagellates. Stable isotope ratios of mussel tissues indicate that $G$. demissa derives a large proportion of its $C$ ultimately from vascular plants Spartina alterniflora (Peterson et al. 1986. Peterson \& Howarth 1987, Langdon \& Newell 1990). However, Kreeger et al. $(1988,1990)$ reported that the mussel's ability to directly utilize refractory cellulosic detritus derived from $S$. alterniflora, although greater than that of other bivalve species, could only contribute a minor share of the mussel's annual $\mathrm{C}$ demand. Our present results support the hypothesis that ribbed mussels obtain at least some of this vascular plant $C$ via the ingestion and assimilation of microheterotrophic intermediaries.

Microheterotroph utilization depends on the mussel's ability to ingest, digest and assimilate such food items. Ingestion depends primarily on particle size. Earlier studies (for review, see Hawkins \& Bayne 1992) have shown that Mytilus edulis, like most suspension- feeders, has only a limited capacity to ingest small, natural-sized $(<1 \mu \mathrm{m})$ bacteria. As an exception, however, Geukensia demissa has been reported capable of filtering natural-sized bacteria with efficiencies 18 to $30 \%$ of those of larger dietary particles (Wright et al. 1982, Riisgård 1988, Langdon \& Newell 1990). Our ingestion results are consistent with these findings. We intentionally cultured cellulolytic bacteria in media that had low $\mathrm{C}$ availability in order to retain the small cell size characteristic of natural populations of estuarine bacteria. A significantly lower proportion (19\%) of these $<1 \mu \mathrm{m}$ bacteria were ingested by $M$. edulis compared with 3 to $5 \mu \mathrm{m}$ bacterivorous flagellates $(58 \%)$. In contrast, there were no significant differences in the proportion of available bacteria, bacterivorous flagellates and microalgae ingested by $G$. demissa; 39,58 and $66 \%$, respectively.

Our finding that bacterivorous flagellates and microalgae were ingested similarly by Geukensia demissa supports the results of Kemp et al. (1990) who reported that $G$. demissa filtered these types of naturally occurring microorganisms with an efficiency of $89 \%$. Kemp et al. (1990) estimated that despite being efficiently captured, heterotrophic flagellates and bacteria comprised only 8 and $10 \%$, respectively, of the total $\mathrm{C}$ filtered by a population of $G$. demissa in a Georgia marsh during August; in comparison, autotrophic algae comprised $75 \%$ of $\mathrm{C}$ filtered. We believe these calculations of Kemp et al. (1990) may not reflect the seasonal role of microheterotrophs in the diet of mussels from all marshes for several reasons. First, stable isotope ratios of mussel tissues seem to indicate that $G$. demissa inhabiting southern salt marshes such as those studied by Kemp et al. (1990) in Georgia derive less C from vascular plants and more $\mathrm{C}$ from phytoplankton (Haines \& Montague 1979) than comparable northeastern (Peterson et al. 1986, Peterson \& Howarth 1987) and mid-Atlantic salt marshes (Langdon \& Newell 1990). Second, Kemp et al. (1990) conducted their filtration measurements during August; however, microheterotrophs may comprise a greater proportion of the particulate seston during months when primary production is minimal (Langdon \& Newell 1990).

Baldwin \& Newell (1995) recently demonstrated that veliger larvae of the eastern oyster Crassostrea virginica can ingest and digest heterotrophic organisms. Although previous studies have shown that bacterivorous nanoflagellates can be ingested by adult suspension-feeding bivalves (for example, see Kemp et al. 1990), ours is the first investigation of the ability of adult bivalve molluscs to digest and assimilate these organisms. Both species of mussels assimilated between 44 and $62 \%$ of $C$ from ingested heterotrophic flagellates, which is moderately lower than the assimilation efficiencies we measured for Geukensia demissa 
feeding on Isochrysis galbana $(77 \%)$. Bacteria were assimilated by $G$. demissa with similar efficiency (42\%) to flagellates; however, Mytilus edulis assimilated bacteria less efficiently ( $21 \%$ ). Assimilation efficiencies of microheteratrophs in situ could differ from these results depending on the digestibility (e.g. cell wall strength and type) of dominant species (Jürgens \& Güde 1994). We assume the heterotrophs used in our work were typical of natural types found in salt marshes. The strain of bacteria was isolated from the same marsh where mussels were collected and is cellulolytic, and the 3 species of flagellates were isolated from coastal systems and are typical of those found in salt marshes (D. Caron pers. comm.).

The majority of studies that have examined the nutritional importance of microheterotrophs have focused on pelagic consumers, such as zooplankton (Gifford \& Dagg 1988, Stoecker \& Capuzzo 1990, Gifford 1991, Sanders \& Wickham 1993). Trophic coupling between pelagic microheterotrophs and benthic suspensionfeeders is typically not considered in modern models of aquatic food webs (e.g. see Legendre \& Le Fèvre 1995). Yet, the biomass of heterotrophic bacteria and flagellates in shallow and hence benthic-dominated aquatic habitats (Davis et al. 1985, Dolan \& Gallegos 1991, Sanders et al. 1992) can exceed the biomass of phytoplankton, and this might be especially true in detritus-dominated salt marshes and during certain times of the year. Since ribbed mussels are able to ingest and assimilate microheterotrophs, we suggest that microheterotrophs could indeed mediate the flow of $C$ from vascular plants to benthic suspension-feeders. This would supplement the ribbed mussel's ability to directly digest refractory lignocellulosic detritus (Kreeger et al. 1988, 1990).

In coastal and estuarine habitats, bivalve molluscs such as mussels are abundant and, as active suspension feeders, they can be the dominant metazoan consumers. More work is needed to characterize the relative availabilities of different food particles over an annual cycle to deduce how bivalves balance their nutritional requirements. Although in this study we examined microheterotroph utilization, it is important to note that mussels are most likely true omnivores, balancing their $\mathrm{C}$ (and $\mathrm{N}$ ) requirements by utilizing a wide variety of living and dead material. In addition to phytoplankton, microzooplankton, and bacteria, mussels can derive nutrition from organic aggregates formed during detritus decomposition (Alber \& Valiela 1994) and perhaps also from benthic diatoms that get suspended in the benthic boundary layer. We are undertaking further field work to examine the diet of Geukensia demissa under field conditions. Our present results clearly suggest, however, that a strong trophic relationship exists between microheterotrophs and suspension-feeding bivalves, which could be of profound importance for the transfer of $\mathrm{C}$ (and probably also $N$ ) from the microbial food web to higher trophic levels (Kemp et al. 1990).

Acknowledgements. We are grateful to Dr D. K. Stoecker for her tireless efforts in helping to design this study, interpret the results, and prepare this report. We thank S. Huang, F. Charles, D. Moreno, D. Gustafson, T McDonnell and R. Clark for their excellent technical assistance. Heterotrophic flagellate cultures were graciously provided by D. A. Caron. We are grateful to Dr Chappas in the Department of Nuclear Engineering at Unuversity of Maryland College Park for gamma irradiation services. R. Sanders provided helpful comments on this manuscript. This study was supported by National Science Foundation Grant \#OCE-9314584 to R.I.E.N., D. K. Stoecker and D.A.K. T. McDonnell and R. Clark were supported by a National Science Foundation Research Experiences for Undergraduates grant to Maryland Sea Grant.

\section{LITERATURE CITED}

Alber M, Valiela I (1994) Assimilation of organic aggregates by marine mussels. Mar Biol 121:259-265

Azam F, Fenchel T, Field JG, Gray JS, Meyer-Reil LA, Thingstad $F$ (1983) The ecological role of water-column microbes in the sea. Mar Ecol Prog Ser 10:257-263

Baldwin BS, Newell RIE (1991) Omnivorous feeding by planktotrophic larvae of the eastern oyster Crassostrea virginica. Mar Ecol Prog Ser 78:285-301

Baldwin BS, Newell RIE (1995) Relative importance of different size food particles in the natural diet of oyster larvae Crassostrea virginica. Mar Ecol Prog Ser 120:135-145

Bayne BL, Newell RC (1983) Physiological energetics of marine Mollusca. In: Saleuddin ASM, Wilbur KM (eds) The Mollusca, Vol 4. Academic Press, New York, p 407-515

Bertness MD (1984) Ribbed mussels and Spartina alterniflora production in a New England salt marsh. Ecology 65: $1794-1807$

Birkbeck TH, McHenery JG (1982) Degradation of bacteria by Mytilus edulis. Mar Biol 72:7-15

Chalermwat K, Jacobsen TR, Lutz RA (1991) Assimilation of bacteria by the dwarf surf clam Mulnia lateralis (Bivalvia: Mactridae). Mar Ecol Prog Ser 71:27-35

Crosby MP, Newell RIE, Langdon CJ (1990) Bacterial mediation in the utilization of carbon and nitrogen from detrital complexes by Crassostrea virginica. Limnol Oceanogr 35: 625-639

Davis PG, Caron DA, Johnson PW, Sieburth JMCN (1985) Phototrophic and apochloritic components of picoplankton and nanoplankton in the North Atlantic: geographic, vertical, seasonal and diel distributions. Mar Ecol Prog Ser 21:15-26

Dolan JR, Gallegos CL (1991) Trophic coupling of rotifers, microflagellates, and bacteria during fall months in the Rhode River Estuary. Mar Ecol Prog Ser 77:147-156

Douillet PA (1993a) Bacterivory in Pacific oyster Crassostrea gigas larvae. Mar Ecol Prog Ser 98:123-134

Douillet PA (1993b) Carbon contribution through bacterivory in larvae of the Pacific oyster Crassostrea gigas. Mar Ecol Prog Ser 102:303-314

Epifanio CE (1982) Phytoplankton and yeast as foods for juvenile bivalves: a review of research at the University of Delaware. In: Pruder GD, Langdon C, Conklin D (eds) Proceedings of the 2nd International Conference of Aquaculture Nutrition: biochemical and physiological ap- 
proaches to shellfish nutrition. Louisiana State University, Baton Rouge, p 292-304

Gifford DJ (1991) The protozoan-metazoan trophic link in pelagic ecosystems. J Protozool 38:81-86

Gifford DJ, Dagg MJ (1988) Feeding of the estuarine copepod Acartla tonsa Dana: carnivory vs. herbivory in natural microplankton assemblages. Bull Mar Sci 43:458-468

Guillard RRL (1975) Culture of phytoplankton for feeding marine invertebrates. In: Smith WL, Chanley MH (eds) Culture of marine invertebrate animals. Plenum Press New York, p 26-60

Guillard RRL, Ryther J (1962) Studies of marine planktonic diatoms. I. Cyclotella nana and Detonula confervacea. Can J Microbiol 8:229-239

Haas LW (1982) Improved epifluorescent microscopic technique for observing planktonic micro-organisms. Ann Inst Océanogr (Paris) 58:261-266

Haines EB, Montague CL (1979) Food sources of estuarine invertebrates analyzed using ${ }^{13} \mathrm{C} /{ }^{14} \mathrm{C}$ ratios. Ecology 60 : $48-56$

Hawkins AJS, Bayne BL (1985) Seasonal variation in the relative utilization of carbon and nitrogen by the mussel Miytilus edulis: budgels, conversion efficiencies and maintenance requirements. Mar Ecol Prog Ser 25:181-188

Hawkins AJS, Bayne BL (1992) Physiological interrelations, and the regulation of production. In: Gosling $E$ (ed) The mussel Mytilus: ecology, physiology, genetics and culture. Elsevier, New York, p 171--222

Hawkins AJS, Navarro E, Iglesias JIP (1990) Comparative allometries of gut-passage time, gut content and metabolic faecal loss in Mytilus edulis and Cerastoderma edule. Mar Biol 105:197-204

Hobbie JE, Daley R, Jasper S (1977) Use of nucleopore filters for counting bacteria by fluorescence microscopy. Appl Env Microbiol 33:1225-1228

Jordan TE, Valiela I (1982) A nitrogen budget of the ribbed mussel, Geukensia demissa, and its significance in nitrogen flow in a New England salt marsh. Limnol Oceanogr $27: 75-90$

Jürgens K, Güde H (1994) The potential importance of grazing-resistant bacteria in planktonic systems. Mar Ecol Prog Ser 112:169-188

Kemp PF, Newell SY, Krambeck C (1990) Effects of filterfeeding by the ribbed mussel Geukensia demissa on the water-column microbiota of a Spartina alterniflora saltmarsh. Mar Ecol Prog Ser 59:119-131.

Kreeger DA, Hawkins AJS, Bayne BL (1996) Use of duallabeled microcapsules to discern the anabolic and catabolic fate of dietary protein in suspension-feeders. Limnol Oceanogr 41:208-215

Kreeger DA, Langdon CJ (1994) Digestion and assimilation of protein by Mytilus trossulus (Bivalvia: Mollusca) fed mixed carbohydrate/protein microcapsules. Mar Biol 118 : $479-488$

Kreeger DA. Lanadon CJ, Newell RIE (1988) Utilization of refractory cellulosic carbon derived from Spartina alterniflora by the ribbed mussel Geukensia demissa. Mar Ecol Prog Ser 42:1.71-179

Kreeger DA, Newell RIE, Langdon CJ (1990) Effect of tidal exposure on utilization of dietary lignocellulose by the ribbed mussel Geukensia demissa (Dillwyn) (Mollusca Bivalvia). J Exp Mar Biol Ecol 144:85-100

Langdon CJ, Newell RIE (1990) Utilization of detritus and bacteria as food sources by two bivalve suspension-feeders, the oyster Crassostrea virginica and the mussel Geukensia demissa. Mar Ecol Prog Ser 58:299-310

Responsible Subject Editor: J. Dolan, Villefranche-sur-Mer, France
Langdon CJ, Newell RIE (1996) Digestion and nutrition of Iarvae and adults. Chapter 6 . In: Kennedy VS, Newell RIE, Eble A (eds) The eastern oyster Crassostrea virginica. Maryland Sea Grant Publication, College Park, MD, p 231-269

Legendre L, Le Fèvre J (1995) Microbial food webs and the export of biogenic carbon in oceans. Aquat Microb Ecol 9: $69-77$

Linley EAS, Newell RC (1984) Estımates of bacterial growth yields based on plant detritus. Bull Mar Sc1 35:409-425

Nagata T, Kirchman DL (1992) Release of macromolecular organic complexes by heterotrophic marine flagellates. Mar Ecol Prog Ser 83:233-240

Newell RC, Field JG (1983a) The contribution of bacteria and detritus to carbon and nitrogen flow in a benthic community. Mar Biol Lett 4:23-36

Newell RC, Field JG (1983b) Relative flux of carbon and nitrogen in a kelp-dominated system. Mar Biol Lett 4: $249-257$

Newell SY, Krambeck C (1995) Responses of bacterioplankton to tidal inundations of a saitmarsh in a filume and adjocent mussel enclosures. J Exp Mar Biol Ecol 190:79-95

Odum EP, de la Cruz AA (1967) Particulate detritus in a Georgia salt marsh-estuarine ecosystem. In: Laulf GH (ed) Estuaries. AAAS Publ 83, Washington, DC, p 383-388

Palmer RE, Williams LG (1980) Effect of particle concentration on filtration efficiency of the bay scallop Argopecten irradians and the oyster Crassostrea virginica. Ophelia 19: $163-174$

Peterson BJ, Howarth RW (1987) Sulfur, carbon and nitrogen isotopes used to trace organic matter flow in the salt-marsh estuaries of Sapelo Island. Limnol Oceanogr 32:1195-1213

Peterson BJ, Howarth RW, Garritt RH (1986) Sulfur and carbon isotopes as tracers of salt-marsh organic matter flow. Ecology 67:865-874

Pomeroy LR (1974) The ocean's food web: a changing paradigm. BioSci 24:499-504

Reid PC, Turley CM, Burkill PH (1991) Protozoa and their role in marine processes. In: Proc NATO Advanced Study Institute, Plymouth, UK 1988. NATO ASI Ecological Series, Springer-Verlag, Berlin, p 506

Riisgård HU (1988) Efficiency of particle retention and filtration rate in 6 species of northeast American bivalves. Mar Ecol Prog Ser 45:217-223

Sanders RW, Caron DA, Berninger UG (1992) Relationships between bacteria and heterotrophic nanoplankton in marine and fresh waters: an inter-ecosystem companson. Mar Ecol Prog Ser 86:1-14

Sanders RW, Wickham SA (1993) Planktonic protozod and metazoa: predation, food quality and population control. Mar Microb Food Webs 7:197-223

Sherr E, Sherr B (1988) Role of microbes in pelagic food webs: a revised concept. Limnol Oceanogr 33:1225-1227

Sokal RR, Rohlf FJ (1981) Biometry, 2nd edn. WH Freeman and Company, New York

Stoecker DK, Capuzzo JM (1990) Predation on protozoa: its importance to zooplankton (review). j Fiankton kes i2: 891-908

Webb KL, Chu FLE (1982) Phytoplankton as a food source for bivalve larvae. In: Pruder GD, Langdon C, Conklin D (eds) Proceedings of the 2nd International Conference of Aquaculture Nutrition: biochemical and physiological approaches to shellfish nutrition. Louisiana State University, Baton Rouge, p 272-291

Wright RT, Coffin RB, Ersing CP, Pearson D (1982) Field and laboratory measurements of bivalve filtration of natural marine bacterioplankton. Limnol Oceanogr 27:91-98

Manuscript first recelved: February 5, 1996

Revised version accepted: September 30, 1996 